\title{
THE TRANSLATION PROCEDURE IN CHILDREN NOVEL - SPIDERWICK CHRONICLE
}

\author{
Gina Larasaty \\ S1 - English Education Deparment \\ Wiralodra University - Indramayu
}

\begin{abstract}
This research aims to find translation procedures from English to Indonesian which are used in translating Spiderwick Chronicles novel. The translator translates from source language (English) to target language (Indonesia). The researcher used the descriptive qualitative method to analyze the data, relates to the aim of this research is to find out the categories of translation procedure in Spiderwick Chronicle Novel. The researcher used the translation procedure (Newmark, 1988:82-91) framework by Peter Newmark for examining the data. Based on the result from the analysis showed that the total number Newmark's translation procedure applied in Spiderwick Novel is 59. The most translation procedure applied is shift or transposition with $20(33,9 \%)$, and the least of translation procedure applied are Cultural equivalent, synonymy and functional equivalent with the total frequency $1(1,7 \%)$. The translator used modulations as the second most translation procedure applied in the Spiderwick novel with $14(23,7 \%)$.
\end{abstract}

\section{Keywords: Translation, Translation Procedures, Spiderwick Chronicle Novel}

\section{INTRODUCTION}

According to Oxford Advanced Learner's Dictionary, Translation is the process of changing something that is written or spoken into another language. (2000:1438). Then, Translation process or activities have been persist, since Greek era. Regarded as the first major translation in the Western World is the translation of The Hebrew bible into Greek in the 3rd BCE.

In the era of globalization, where technology is growing rapidly. In line with that the translation needs are increasingly developing to access various information. Nowadays, the translation needs are increasing not only for formal books such as educational books but translation for literary books is also increasing, one of them is a translation for novels. Many foreign popular novels or best seller novels are translated into Indonesia Language.

Translating novel is more difficult than translating academic text. Translating Novel is a literary forms, the second most difficult after translating poetry. Newmark (1998: 106) "...literary writing is the creating of images in the mind and their realization on paper, the creation of fiction". One of the problem in translating novel is translating culture. Newmark (1988: 171). Novel is length than short story with more complex story on it.

This study used the children Novel - Spider wick Chronicles by Tonny Diterlizzi and Holly Black as data. In this novel there are many expression that sometimes difficult for young reader, so the translator should be aware to choose the appropriate expression for the young reader when translating the novel from source language into target language. And to make good translation, the translator should be smart in using proper translation procedure. In other words, this study focused on to find out what kind of translation procedure applied in Spiderwick Chronicles Novel which has been translated from English (source language) to Target Language (Indonesia) by Donna Widjajanto. 


\section{Gina Larasaty \\ THE TRANSLATION PROCEDURE \\ IN CHILDREN NOVEL - SPIDERWICK CHRONICLE}

\section{LITERATURE REVIEW}

According to Nida and Taber (1974:13), "translating consists in reproducing in the receptor language the closest natural equivalent of the source language message, first in terms of meaning and secondly in terms of style". Later, Newmark (1988:7) gives a similar statement that "translation is a craft consisting in the attempt to replace a written message and/or statement in another language". In other words. Translating is the activity to replace the message from source language to target language. In order to be acceptable into target language, the translator needs procedure in translating text. In doing translation, the translator have to apply translation procedure to make equivalent with the target language.

According Newmark (1988:81) stated that there some types of translation procedures :

1. Transference: it is the process of transferring an SL word to a TL text. It includes transliteration and is the same as what Harvey (2000:5) named "transcription."

2. Naturalization: it adapts the SL word first to the normal pronunciation, then to the normal morphology of the TL. (Newmark, 1988b:82)

3. Cultural equivalent: it means replacing a cultural word in the SL with a TL one. however, "they are not accurate" (Newmark, 1988b:83)

4. Functional equivalent: it requires the use of a culture-neutral word. (Newmark, 1988b:83)

5. Descriptive equivalent: in this procedure the meaning of the CBT is explained in several words. (Newmark, 1988b:83)

6. Componential analysis: it means "comparing an SL word with a TL word which has a similar meaning but is not an obvious one-to-one equivalent, by demonstrating first their common and then their differing sense components." (Newmark, 1988b:114)

7. Synonymy: it is a "near TL equivalent." Here economy trumps accuracy. (Newmark, 1988b:84)

8. Through-translation: it is the literal translation of common collocations, names of organizations and components of compounds. It can also be called: calque or loan translation. (Newmark, 1988b:84)

9. Shifts or transpositions: it involves a change in the grammar from SL to TL, for instance, (i) change from singular to plural, (ii) the change required when a specific SL structure does not exist in the TL, (iii) change of an SL verb to a TL word, change of an SL noun group to a TL noun and so forth. (Newmark, 1988b:86)

10. Modulation: it occurs when the translator reproduces the message of the original text in the TL text in conformity with the current norms of the TL, since the SL and the TL may appear dissimilar in terms of perspective. (Newmark, 1988b:88)

11. Recognized translation: it occurs when the translator "normally uses the official or the generally accepted translation of any institutional term." (Newmark, 1988b:89)

12. Compensation: it occurs when loss of meaning in one part of a sentence is compensated in another part. (Newmark, 1988b:90)

13. Paraphrase: in this procedure the meaning of the CBT is explained. Here the explanation is much more detailed than that of descriptive equivalent. (Newmark, 1988b:91)

14. Couplets: it occurs when the translator combines two different procedures. (Newmark, 1988b:91)

15. Notes: notes are additional information in a translation. (Newmark, 1988b:91) 


\section{RESEARCH METHOD}

As in this study is aimed to describe about the translator's procedure in translate the 2nd book of Spiderwick Chronicles "The Seeing Stone". This study used the qualitative research design. According to McInroy (1986: 3), qualitative research is concerned with a quality of information, qualitative methods attempt to gain an understanding of the underlying reasons and motivations for actions and establish how people interpret their experiences and the world around them. Then, according to Cresswel (1994: 39), qualitative research focuses on the process that is occurring as well as the product or outcome. It can be concluded that qualitative research is concerned on yielding an understanding of the types, processes and reasons of occurred phenomena. So that is why the researcher interested in understanding what, why and how something happen with translation, such as what are the translation procedure in translating Novel "The 2nd Novel of Spiderwick Chronicles ".

The source of data in this research is both English and Indonesia versions of "the 2nd of Spiderwick Chronicles" Novel. The data is collected using documents and will be analyzed related to the theories.

In collecting data, there are some steps; (1) Reading original novels and the translated Novel repeatedly, (2) marking words, phrases, clauses and sentences that have potential to become data, (3) enter it into the table, (4) give the code from the data.

\section{FINDING AND DISCUSSION}

\section{Finding}

Table.1. List of Newmark's Translation Procedure

\begin{tabular}{|l|l|l|l|}
\hline No & Translation Procedure & Frequency & Percentage \\
\hline 1 & Transference & 6 & $10,2 \%$ \\
\hline 2 & Naturalization & 2 & $3,4 \%$ \\
\hline 3 & Cultural Equivalent & 1 & $1,7 \%$ \\
\hline 4 & Synonymy & 1 & $1,7 \%$ \\
\hline 5 & Shift or transposition & 20 & $33,9 \%$ \\
\hline 6 & Modulation & 14 & $23,7 \%$ \\
\hline 7 & functional Equivalent & 1 & $1,7 \%$ \\
\hline Total & 59 & $100 \%$ \\
\hline
\end{tabular}

In Table 1 showed that there are seven translation procedures by Newmark applied in Spiderwick Chronicles Novel. There are; Transference, Naturalization, cultural equivalent, Synonymy, Shift, modulation and functional Equivalent. The most translation procedure applied is shift or transposition with $20(33,9 \%)$, and the least of translation procedure applied are cultural equivalent, synonymy and functional equivalent with the total frequency $1(1,7 \%)$. The translator allowed to transfer the meaning as long as it does not change the original meaning or purpose.

\section{Discussion}

Case 1

\begin{tabular}{|l|l|l|l|}
\hline Procedure & SL & TL & page \\
\hline Transference & $\begin{array}{l}\text {...that looked suspiciously } \\
\text { like poison ivy }\end{array}$ & $\begin{array}{l}\text {...dedauanan yang } \\
\text { mirip poison ivy }\end{array}$ & 67 \\
\hline
\end{tabular}

"As he edged along, Jared could not help looking down. In the cages below, he could see squirrels, cat and birds. Some were clawing and biting at the bars, while others unmoving. A few contained just bones. They were all lined with leaves that looked suspiciously like poison ivy."

Poison ivy is a plant that can cause a rash on your skin or itchy, this plants grows in bushes and spreads. Poison ivy is translated poison ivy by the translator, 
because there is no equivalent the word poison ivy in TL. This translation procedure is considered as transference. The translator used the foreign terms or borrowing from SL.

Case 2

\begin{tabular}{|l|l|l|l|}
\hline Procedure & SL & TL & page \\
\hline Naturalization & $\begin{array}{l}\text {... An interrogation? } \\
\text { Hogsquel groused }\end{array}$ & $\begin{array}{l}\text {.. interogasi?' gerutu } \\
\text { Hogsquel }\end{array}$ & 75 \\
\hline
\end{tabular}

"What is this?" an Interrogation? Hogsquel groused.

Interrogation has meaning as a series of question or doing interview as commonly employed by law enforcement officers, military personnel. The translator translated the word "interrogation" into "Interogasi". The translator adapts the normal pronunciation first, then to normal morphology in TL. And this translation is considered as Naturalization. In TL the word interrogation has a equivalent.

Case 3

\begin{tabular}{|l|l|l|l|}
\hline Procedure & SL & TL & Page \\
\hline $\begin{array}{l}\text { Cultural } \\
\text { Equivalent }\end{array}$ & $\begin{array}{l}\text { By Fence. Have you no } \\
\text { sense?” }\end{array}$ & $\begin{array}{l}\text { Di dekat pagar sana. } \\
\text { Kau Buta, ya? }\end{array}$ & 11 \\
\hline
\end{tabular}

"Have you no sense "means asking about the awareness or feeling about something. And the translator translated "Have you no sense "become "kau buta, ya?" in TL. The translator relates the words sense about tasting, touching, seeing and hearing, so the translator transfer the meaning of " have no sense " become "kau buta ya?". This translation is type of cultural equivalent, because it approximate cultural equivalent in TL based on the context

Case 4.

\begin{tabular}{|l|l|l|l|}
\hline Procedure & SL & TL & Page \\
\hline $\begin{array}{l}\text { Functional } \\
\text { Equivalent }\end{array}$ & $\begin{array}{l}\text { Until the monocle } \\
\text { apparatus was on tight }\end{array}$ & $\begin{array}{l}\text { Jared harus agak } \\
\text { meyipitkan } \\
\text { matannya supaya } \\
\text { bisa melihat dengan } \\
\text { jelas }\end{array}$ & \\
\hline
\end{tabular}

"Honere, Let me tie it on your head right." Mallory knotted the leather straps until the monocle - apparatus was on tight.

The words "Monocle- Apparatus "is the officer who is wearing a single round lens for one eye. This apparatus do not exist in TL. But if the words are translated like that into the target language, the context will be inappropriate. So, the words "Monocle - apparatus "is translated into "menyipitkan matanya supaya bisa melihat". The translator used functional equivalent as translator procedure to neutralise or generalise a SL cultural word.

Case 5

\begin{tabular}{|l|l|l|l|}
\hline Procedure & SL & TL & Page \\
\hline Shift & $\begin{array}{l}\text { He couldn't } \\
\text { believe he'd had } \\
\text { to stay after } \\
\text { school already }\end{array}$ & $\begin{array}{l}\text { Dia tak bisa } \\
\text { percaya dia } \\
\text { dihukum harus } \\
\text { tinggal di sekolah } \\
\text { setelah jam } \\
\text { pelajaran usai. }\end{array}$ & 1 \\
\hline
\end{tabular}


The word "he" has specific meaning in SL, in which he refers to a man, boy, or male animal. But the translator translated into "dia", in which "dia" is more general that may refers to women or man. This procedure is called shift in translation and the type of this shifts is specific to general. This type of shift more appears than other type such as; "....still fighting some invisible foe." The word Invisible is translated into "Tak terlihat". This shift is called level shift. It means that a SL word has equivalent in different linguistic level. And this case occurs in the level of morpheme. It can be seen that the bound morpheme in SL (In- visible) has different level in TL. In TL is not bound morpheme but free morpheme (tak terlihat).

Case 6

\begin{tabular}{|l|l|l|l|}
\hline Procedure & SL & TL & Page \\
\hline Modulation & $\begin{array}{l}\text { The print below } \\
\text { it was made } \\
\text { huge }\end{array}$ & $\begin{array}{l}\text { Benda itu membuat } \\
\text { tulisan di } \\
\text { bawahnya besar }\end{array}$ & 21 \\
\hline
\end{tabular}

Modulation is making variation in TL through changing a viewpoint. There are many type of modulation such as: a part to whole, abstract to concrete, cause to effect, active to passive, etc. But in this case, the translator tries to translate from SL to TL using modulation passive to active.

Case 7

\begin{tabular}{|l|l|l|l|}
\hline Procedure & SL & TL & Page \\
\hline synonymy & $\begin{array}{l}\text { There was a faint } \\
\text { sound inside the } \\
\text { wall }\end{array}$ & $\begin{array}{l}\text { Ada suara lembut } \\
\text { dari dalam dinding }\end{array}$ & 8 \\
\hline
\end{tabular}

The word "faint" has close meaning weak as to be difficult to perceive; a faint light in distance; a faint echo and to use a near TL equivalent to SL in a context, the translator used the synonym. The translator use the synonymy of "faint" is soft to make a near TL equivalent to SL word. The translator has to make compromise in order to make the meaning of translation more accurately by doing synonymy.

\section{CONCLUSION}

The conclusion of this research based on the data analysis and discussion are; the total number for the translation procedure used in Spiderwick Chronicle Novel is 59 $(100 \%)$. The results are transference with $6(10,2 \%)$, Naturalization with $2(3,4 \%)$, Cultural equivalent, synonymy and functional equivalent with $1(1,7 \%)$, shift or transposition with $20(33,9 \%)$ and the last modulation with $14(23,7 \%)$.

From the result above, the researcher concludes that the translation procedure mostly applied in shift or transposition with 20 time occurrence $(33,9 \%)$. Then, the translator still concerned with grammar and make transposition intuitively.

\section{REFERENCES}

McIrony, Stuart \& Headlam, N. 1986. Research Methods Handbook: Introductory Guide to Research Methods for Social Research. Center

Cresswel, J.W 1994. Research Design Qualitative Quantitative Approaches. London: Sage.

Nida, Eugene A. and Charles R. Taber. 1974. The theory and practice of Translation. Netherlands: E. J. Jovanovich, Leiden

Newmark, Peter. 1988. A Textbook of Translation. UK: Prentice Hall. 